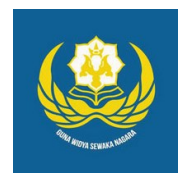

Jurnal Analogi Hukum

Journal Homepage: https://ejournal.warmadewa.ac.id/index.php/analogihukum

\title{
Perjanjian Pinjam Meminjam Uang Antara Renternir Dengan Konsumen di Pasar Desa Adat Mengwi
}

\author{
Ni Ketut Diah Prihandani*, Desak Gde Dwi Arini dan Ni Made Puspasutari Ujianti \\ Universitas Warmadewa, Denpasar-Bali, Indonesia \\ *kd.prihandani@gmail.com
}

\begin{abstract}
How To Cite:
Prihandani, N, K, D., Arini, D, G, D., Ujianti, N, M, P. (2021). Perjanjian Pinjam Meminjam Uang Antara Renternir Dengan Konsumen di Pasar Desa Adat Mengwi. Jurnal Analogi Hukum. 3 (1). 47-51. Doi: https://doi.org/10.22225/ah.3.1.3031.47-51

Abstract-The debts or lending money is one of those things that is never ended, in the practiced borrowed money related to loan shark and consumer borrowed to practiced of the money between loan shark and consumer, that is many to founded in Desa Adat Mengwi market which debt agrement among loan shark and consumer is agrement among the two parties is sometimes weaknes of law. So if a default occurs in this agrement it will be difficult to reselved, based on the problem, two problem statements can be formulated 1 . How legitimate the loan agrement is between loan shark and consumer in the Desa Adat Mengwi market and, 2. What legal efforts will do if there is a default on consumers. In solving those problem, the settlement method used is an empirical research method. With research directly collecting data used through interview and used the sociology approach, from the result of real research. Legitimate lending and borroming agrements among loan shark and consumers in Desa Adat Mengwi market guided by justice, that is the evert of default between loan shark and consumer and debt agrement, this is the factor that from consumers thenselves and affort to solve that are used are non litigation or community.
\end{abstract}

Keywords: Agreement; borrowing; borrower; consumers; default; loan shark; money

\begin{abstract}
Abstrak-Hutang piutang atau pinjam meminjam uang merupakan salah satu hal yang tidak pernah usai dalam praktek pinjam meminjam uang sangat berkaitan dengan renternir dan pihak konsumen peminjam. Praktek pinjam meminjam uang antara rentenir dengan konsumen ini banyak terdapat di Pasar Desa Adat Mengwi, yang dimana perjanjian hutang piutang antara renternir dengan konsumen peminjam. Kegiatan perjanjian pinjam meminjam uang antar kedua belah pihak ini terkadang lemah hukum. Sehinga, jika terjadi wanprestasi dalam perjanjian ini maka akan sulit untuk diselesaikan. Berdasarkan hal ini maka dapat dirumuskan dua rumusan masalah 1. Bagaimana sahnya perjanjian pinjam meminjam antara renternir dan konsumen di Pasar Desa Adat Mengwi dan, 2. Upaya hukum apakah yang dilakukan renternir apabila terjadi wanprestasi pada konsumen. Dalam memecahkan permasalahan tersebut metode penyelesaian yang digunakan adalah metode penelitian empiris dengan penelitian secara langsung pengumpulan data yang digunakan melalui wawancara dan menggunakan pendekatan sosiologis. Dari hasil penelitian dilapangan, Sahnya perjanjian pinjam meminjam uang antar renternir dan konsumen peminjam di Pasar Desa Adat Mengwi berpedoman pada Pasal 1320 yaitu dalam hal wanprestasi antar renternir dan konsumen terhadap perjanjian hutang piutang ini faktor penyebabnya berasal dari diri konsumen sendiri dan upaya penyelesaian yang digunakaan adalah secara non litigasi atau musyawarah.
\end{abstract}

Kata kunci: Perjanjian; Pinjam meminjam; renternir; konsumen peminjam; wanprestasi; uang

\section{Pendahuluan}

Manusia dalam kehidupannya selaku makhluk sosial selalu berhubungan dan berinteraksi antar manusia lainnya dengan meliputi beberapa aspek, diantaranya aspek sosial, budaya dan hukum, termasuk perdata (Hartana, 2016). Pinjam meminjam uang merupakan salah satu persoalan yang tidak akan pernah bisa usai untuk dibicarakan. Tidak dapat kita pungkiri bahwa persoalan pinjam meminjam ini sangat berhubungan dengan praktek Renternir dimana Renternir meminjamkan uangnya terhadap Konsumen Peminjam, dalam hal praktek pinjam meminjam antara Renternir dengan konsumen peminjam ini timbul sebuah 
hubungan hukum, hubungan hukum ini disebut perjanjian pinjam meminjam uang. Perjanjian pinjam meminjam ini seringkali lemah hukum karena keadaan lemah hukum ini maka dapat dimaklumi sering terjadinya tindakan wanprestasi misalnya konsumen yang tidak dapat memenuhi isi perjanjian yang dibuatnya atau tidak dapat memenuhi kewajibannya

Praktek pinjam meminjam uang antara Renternir dan Konsumen ini banyak terdapat di Pasar Desa Adat Mengwi, praktek ini banyak dilakukan di Pasar Desa Adat Mengwi dikarenakan proses peminjaman yang mudah untuk didapatkan dan bahkan dengan jumlah pinjaman yang sangat tinggipun tidak memakai jaminan dengan alasan kepercayaan saja.

Walaupun dalam kenyataanya praktek ini sangatlah mencekik konsumen peminjam karena dalam praktek ini Renternir seringkali menetapkan bunga yang sangat besar bahkan sampai $10 \%$ dari pinjamannya. Meskipun praktek pinjam meminjam antar Renternir dengan Konsumen ini lemah hukum dan banyak menimbulkan permasalahan seperti yang telah dijelaskan diatas bahwa peluang terjadinya sengketa wanprestasi itu sangatlah mungkin karena konsumen pastilah mengalami kesulitan dalam memenuhi kewajibannya dikarenakan nilai pinjaman yang dengan bunga sangat tinggi. dengan timbulnya permasalahanpermasalahan ini maka penulis tertarik untuk mengangkat judul "Perjanjian Pinjam Meminjam Uang Antara Renternir Dan Konsumen Di Pasar Desa Adat Mengwi”.

Dari uraian latar belakang diatas maka penulis mendapatkan dua rumusan masalah yaitu:

Bagaimanakah sahnya perjanjian pinjam meminjam antara Renternir dan konsumen di Pasar Desa Adat Mengwi?

Upaya hukum apakah yang dilakukan Renternir apabila terjadi Wanprestasi pada Konsumen?

Penelitian ini bertujuan untuk mengetahui tentang sahnya perjanjian pinjam meminjam uang antara renternir dan konsumen di Pasar Desa Adat Mengwi dan untuk mengetahui tentang upaya hukum yang dilakukan Renternir pada saat Konsumen melakukan tindakan wanprestasi.

\section{Metode}

Untuk menjawab rumusan masalah yang ada penulis menggunakan metode penelitian Empiris dimana penulis melakukan penelitian secara langsung kelapangan dan pendekatan secara sosiologis dengan menggunakan sumber data primer dengan mengadakan penelitian secara langsung dan dengan wawancara dengan pihak yang terkait dan sumber data sekunder yaitu menelaah literatur-literatur yang berkaitan dengan skripsi ini.

Penelitian ini berlokasi di Pasar Desa Adat Mengwi, Kecamatan Mengwi, Kabupaten Badung, setelah semua data terkumpul maka data tersebut diolah secara kualitatif dengan menganalisis permasalahan yang timbul dan temui di lapangan.

\section{Hasil Penelitian dan Pembahasan}

\section{Sahnya Perjanjian Pinjam Uang Antara Renternir dengan Konsumen Di Pasar Desa Adat Mengwi}

Perjanjian terdapat dua bentuk yaitu perjanjian secara tertulis dan secara lisan, perjanjian tertulis memiliki kekuatan pembuktian yang lebih kuat perjanjian tertulis tertuang dalam dua bentuk yaitu dalam bentuk akta otentik dan dalam bentuk akta dibawah tangan, sementara perjanjian yang dilakukan secara lisan memiliki kekuatan pembuktian yang lemah karena salah satu pihak dapat menyangkal bahwa telah melakukan kesepakatan dalam sebuah perjanjian menyangkal bahwa telah melakukan sebuah perikatan.

Perjanjian pada umumnya adalah suatu kesepakatan yang menimbulkan kewajiban antara keduabelah pihak, yang satu berkewajiban untuk memberikan suatu prestasi dan pihak yang lainnya mempunyai hak untuk mendapatkan prestasi tersebut (Miru, 2007). Perjanjian pada umumnya diatur dalam pasal 1313 KUHPerdata (Muhamad, 2011). Mengenai pengaturan terhadap perjanjian pinjam meminjam diatur dalam pasal 1754 KUHPerdata dimana dalam pengaturannya mewajibkan seseorang yang meminjam sejumlah uang maka seseorang itu harus mengembalikannya dengan jumlah yang sama sesuai dengan kesepakatan antara kedua belah pihak.

Sehubungan dengan hal tersebut diatas maka perjanjian pinjam meminjam uang antara renternir dan konsumen merupakan kesepakatan antara Renternir dengan konsumen yang mana perjanjian ini lahir pada saat Renternir menyerahkan sejumlah uang kepada konsumen.

Dari hubungan kesepakatan yang terjadi atau dari perjanjian pinjam meminjam uang antara Renternir dan konsumen maka Renternir 
dan Konsumen memiliki hak dan kewajiban masing masing, seperti yang telah terjadi dalam Praktek pinjam meminjam uang di pasar Desa Adat yang dimana hal ini diterangkan pada wawancara pada tanggal 15 Desember 2018 dengan $\mathrm{Ni}$ Wayan Kembar Yiani yang merupakan seorang Renternir Di Pasar Desa Adat Mengwi, hak yang didapatkan beliau sebagai Renternir adalah:

Menerima kembali uang yang telah dipinjamkan kepada konsumen dengan jumlah yang sama

Menerima bunga dari pinjaman tersebut sesuai dengan kesepakatan berapa besarnya bunga yang telah di tentukan.

Menangih hutang kepada konsumen sesuai dengan batas waktu yang telah disepakati

Menangih ganti rugi apabila konsumen telah lalai dalam menunaikan kewajibannya.

Dan kewajiban dari Renternir adalah renternir tidak diperbolehkan menagih hutang kepada konsumen jika belum pada batas waktu yang telah di tentukan, Renternir berkewajiban untuk memberikan batas waktu pinjaman, dan renternir harus memberikan pilihan bagaimana tatacara pembayaran yang diinginkan oleh konsumen seperti pembayaran dengan mencicil setiap hari atau mencicil dengan membayar setiap bulan.

Menurut hasil Wawancara pada tanggal 11 Desember 2018 dengan ibu Indah yang dimana beliau merupakan konsumen peminjam di pasar desa adat mengwi hak yang beliau dapatkan dari perjanjian pinjam meminjam ini adalah menerima sejumlah uang yang dimana telah disepakati antara beliau dengan Renternir dan mendapatkan perpanjangan waktu jatuh tempo apabila beliau telat dalam melakukan pembayaran. Dan kewajiban yang beliau harus lakukan adalah sebagai berikut:

Harus mengembalikan uang yang telah beliau pinjam tepat pada waktu yang telah beliau sepakati dengan renternir pada awal perjajian itu dibuat.

Beliau tidak boleh mengembalikan uang jika belum pada waktu yang telah ditentukan.

Membayarkan pinjaman dengan bunga yang telah beliau sepakati dengan renternir pada perjanjian pinjam meminjam uang.

Beliau harus menerima sanksi apabila beliau telah melalaikan kewajiban sesuai dengan kesepakan yang telah beliau buat.
Dari pemaparan tersebut perjanjian pinjam meminjam uang antara Renternir Dengan Konsumen di Pasar Desa Adat Mengwi yang dimana dinyatakan dalam wawancara pada tanggal 15 Desember 2018 dengan Ni Wayan Kembar Yani sahnya perjanjian pinjam meminjam yang beliau lakukan telah berpedoman pada syarat sahnya perjanjian yang mana telah diatur pada pasal 1320 KUHPerdata dimana dalam pengamatan dilapangan sahnya tersebut adalah:

Adanya persesuaian kesepakatan antara Renternir dengan Konsumen peminjam di pasar Desa Adat mengwi seperti berapa jumlah bunga yang akan konsumen bayar dan bagaimana tatacara pembayaran yang diinginkan oleh konsumen

Kecakapan antara Renternir dan konsumen dimana kecakapan ini dilihat dari umur konsumen dan renternir yang telah memenuhi kecakapan, Renternir dan Konsumen tidak dalam pengampuan.

Perjanjian yang dibuat oleh Renternir dan Konsumen memiliki objek perjanjian yang tertentu dalam perjanjian ini objek tersebut adalah uang

Sebab yang halal perjanjian yang dilakukan oleh Renternir dan konsumen tidak bertentangan dengan peraturan perundangundangan yang ada.

\section{Upaya Hukum yang Dilkukan Renternir dengan Konsumen Apabila Terjadi Wanprestasi}

Dalam perjanjian pinjam meminjam uang antara renternir dan konsumen tidak bisa dipungkiri terjadinya suatu permasalahan karena perjanjian yang dilakukan seringkali lemah hukum permasalahan yang timbul biasanya tindakan wanprestasi. wanprestasi pada umumnya merupakan dimana tidak terpenuhinya atau lalai melaksanakan kewajiban sebagaimana yang telah di tentukan pada perjanjian yang telah disepakati (Yahman, 2014).

Untuk mengatakan bahwa seseorang telah melakukan tindakan wanprestasi dapat diketahui dengan tiga keadaan yaitu:

Konsumen tidak memenuhi prestasi/ kewajibannya sama sekali berati salah satu pihak disini tidak melaksanakan kewajibannya sama sekali.

Konsumen memenuhi prestasinya tetapi 
tidak dengan baik artinya konsumen atau salah satu pihak memenuhi kewajibannya tetapi tidak segaimana yang telah dijanjikan

Konsumen memenuhi prestasinya tetapi tidak tepat pada waktunya berarti konsumen telah memenuhi isi perjanjiannya tetapi tidak pada waktu yang telah ditentukan diperjanjian

Melakukan sesuatu yang dimana dalam perjanjian tidak boleh untuk dilakukan.

Secara umum tidak terpenuhinya isi perjanjian dikarenakan oleh dua keadaan yaitu:

Karena kesalahan konsumen baik disengaja maupun tidak disengaja ataupun kelalaian dari konsumen

Karena keadaan memaksa yang diluar kemampuan konsumen atau kemampuan tidak bersalah

Dalam konteks perjanjian pinjam meminjam uang antara Renternir dengan Konsumen wanprestasi adalah tidak terpenuhinya isi perjanjian yang telah dibuat dan disepakati oleh Renternir dan Konsumen, dari hasil pengamatan di lapangan tindakan wanprestasi terhadap perjanjian pinjam meminjam uang antara Renternir degan konsumen sering terjadi di Pasar Desa Adat Mengwi, dimana konsumen peminjam tidak menunaikan dengan baik isi perjanjian yang telah disepakati.

Berdasarkan wawancara pada tanggal 15 Desember 2018 dengan Ni Waya Kembar Yani faktor- faktor yang mengakibatkan terjadinya tindakan wanprestasi ini adalah faktor yang dimana berasal dari diri konsumen itu sendiri seperti:

konsumen tersebut memang memiliki itikad tidak baik dalam meminjam uang terhadap renternir.

Konsumen mengalami musibah sehingga konsumen tidak dapat membayar hutangnya

Kebutuhan mendesak yang harus
didahulukan

Karena dalam penelitian ini berkonteks di pasar yang tentunya konsumen peminjam ini kebanyakan merupakan pedagang di pasar Desa Adat Mengwi dan usaha yang mereka geluti tersebut mengalami kebangkrutan sehingga konsumen peminjam tidak mampu dalam membayar hutangnya.

Karena pangsa pasar yang turun mengakibatkan pendapatan konsumen pun menurun sehingga mengakibatkan tersendatnya dalam pembayaran hutang.

Dalam menyelesaikan sengketa wanprestasi dapat diselesaikan dengan cara penyelesaian secara litigasi dan non litigasi. Dalam penyelesaian sengketa wanprestasi dilakukan dengan cara non litigasi atau diluar pengadilan dilakukan dengan beberapa tahap:

Tahap persiapan

Dimana dalam tahap ini para pihak mempersiapkan diri dengan sungguh-sungguh dan tekat yang kuat untuk menyelesaikan perkara dengan baik-baik

\section{Tahap mempelajari kasus posisi}

Dalam tahap ini terdapat beberapa hal yang harus mendapat perhatian yaitu, kebenaran subjek dan objek dalam sebuah perjanjian, hubungan perikatan antara keduabelah pihak, hak dan kewajiban yang dimiliki oleh kedua belah pihak

\section{Tahap perlindungan}

Dimana dalam tahap ini dapat dilakukan langsung oleh masing-masing pihak yang bersengketa dengan perwakilan kuasa atau pihak ketiga, dalam tahap ini juga harus terdapat pemihasan antara masalah dengan subjek yang bersengketa. dan pada tahap ini harus berkonsentrasi pada sengketa yang terjadi

\section{Tahap perumusan hasil}

Dalam tahap ini yang perlu diperhatikan bahwa rumusan hasil dari mediasi yang dilakukan harus tertulis, harus menggunakan katakata atau bahasa hukum yang tepat, memberikan kesepakatan untuk ditanggapi, mengingat batas waktu penyelesaian rumusan kesepakatan

\section{Tahap pelaksanaan hasil}

Dalam tahap ini hasil dari kesepakatan yang terjadi dilaksanakan menurut UndangUndang No. 30 tahun 1999 tepatnya pada pasal 6 ayat 8 .

Menurut wawancara dengan $\mathrm{Ni}$ Wayan Kembari Yani sebagai pemberi pinjaman (Renternir) penyelesaian sengketa wanprestasi yang beliau lakukan dalam menyelesaikan sengketa wanprestasi saat konsumen mengalami wanprestasi adalah dengan cara non litigasi atau musyawarah dengan menegur konsumen secara baik-baik dengan cara lisan, memberi tahukan sanksi hutang yang dimiliki oleh renternir, dan memperbaharui isi perjanjian apabila konsumen 
menginginkan hal tersebut. Seseorang yang tidak memenuhi isi perjanjian maka seseorang tersebut harus memberikan ganti kerugian meliputi: kan.

Ganti rugi atas semua biaya yang di keluar-

Kerugian yang dikarenakan kerusakan dan kehilanggan.

Keuntungan yang diharapkan.

Ganti kerugiaan diatur dalam pasal 1234 KUHPerdata dimana dalam konteks perjanjian pinjam meminjam uang antara renternir dengan konsumen ganti kerugian yang timbul karena kelalaian dari konsumen atau konsumen telah cidera janji.

Suatu permasalahan dapat diselesaikan apabila diantara keduabelah pihak menyadari bagaimana hak dan kewajiban mereka masingmasing sehingga permasalahan tersebut dapat diselesaikan dengan baik dan hubungan antara kedua belah pihak tetap terjaga.

\section{Simpulan}

Jadi dapat disimpulkan bahwa; sahnya perjanjian pinjam meminjam uang antara Renternir dan Konsumen di Pasar Desa Adat Mengwi berpedoman pada syarat sahnya perjanjian yaitu pasal 1320 KUHPerdata dimana, harus adanya kesepakatan antara Renternir dengan Konsumen Renternir dan Konsumen harus cakap dalam Membuat suatu perjanjian harus adanya objek tertentu yang pasti dalam membuat suatu perjanjian perjanjian tersebut tidak boleh bententangan dengan kausa yang halal atau tidak bertentangan dengan Undang-Undang dan Peraturan yang ada dan kesusilaan.

Upaya hukum yang dilakukan Renternir pada saat Konsumen wanprestasi adalah Penyelesaian secara Non litigasi secara musyawarah dengan menegur secara baik-baik konsumen yang melakukan tindakan wanprestasi memberitahu keluarga akan sanksi yang dimiliki renternir memperbaharui isi perjanjian jika dibutuhkan.

\section{DAFTAR PUSTAKA}

Hartana. (2016). Batubara), Hukum Perjanjian (Dalam Perspektif Perjanjian Karya Pengusahaan Pertambangan. Jurnal Komunikasi Hukum, 2(2). Retrieved from https://ojs.unud.ac.id/index.php/ kerthasemaya/article/

download/60869/35124/
Miru, A. (2007). Hukum Kontrak dan Perancangan Kontrak. jakarta: Raja Wali Pers.

Muhamad, A. (2011). Hukum Perikatan. Bandung: PT. Citra AdityaBakti.

Yahman. (2014). Karakteristik WANPRESTASI dan Tindak Pidana Penipuan. Jakarta: Prenada Media Grub. 